\title{
Education and Social Integration: a comparative study of the comprehensive school system in Scandinavia
}

\author{
SUSANNE WIBORG \\ The Danish University of Education, Copenhagen, Denmark
}

\begin{abstract}
The purpose of this article is to outline a framework of explanation of the unique tradition of comprehensive schooling in Scandinavia. All the countries developed an all-through system of education from grade one to nine/ten with mixed ability classes for nearly all. This allthrough system of education is a product of a long historical development. It will be argued that four factors shaped this development: strong state involvement, a relative egalitarian class structure, powerful Liberal Party and a strong Social Democracy.
\end{abstract}

\section{Introduction}

Most European countries in the past half-century have taken steps to reduce educational inequality, notably through the introduction of comprehensive schooling. The Scandinavian countries introduced non-selective schools throughout the state sector; England, Wales and Scotland, for the most part, did the same, although in England there remained some pockets of selective secondary schooling. Even in Germany, where the majority of secondary schools are selective, a parallel, mixed-ability Gesamtschule was introduced to pursue a common base for learning. However, these countries show considerable differences in how successful they have been in adopting the comprehensive school form and in the degree to which this has contributed towards a reduction in educational inequality.

Education is certainly not the only means for enhancing equality in societies, although many believe it plays an important role. However, as the available research shows, this can be hard to demonstrate conclusively, particularly in relation to the effects of comprehensive schooling. Some studies argue that comprehensive education has had little effect on reducing inequality compared to the effects of other social welfare measures, such as universal state childcare (Esping-Andersen, forthcoming). Other studies suggest it has a rather important effect in certain regions (Jonsson on Sweden in Shavit \& Blossfeld, 1983). The OECD's Programme for International Student Assessment (PISA) now provides more comprehensive data on the achievements of 15 -year-olds in a range of countries which may be used to explore this question. In their analysis (OECD, 2000) the OECD use various measures of educational inequality, including those for dispersal of skills in reading, numeracy and basic science, social intake mix in schools, and the strength of social inheritance (in terms of parental wealth, occupation, education, and cultural capital 


\section{S. Wiborg}

combined) in determining educational outcomes. The latter measure, the strength of social inheritance, suggests clear regional variations (as do several other measures).

The advanced countries where social inheritance appears to have the least effect on educational outcomes are the Nordic countries (Sweden and Iceland less than Denmark, Norway and Finland) as well as Korea, Japan and Spain (OECD, table 8.1). The countries where it has the greatest impact are: Germany, Switzerland, UK, USA, Belgium, France, Australia and New Zealand. The Nordic and East Asian countries tend to predominate amongst the more educational equal countries. Anglo-Saxon countries and countries in the region close to Germany tend to be most unequal. Amongst the unequal group, five of the ten systems are selective at secondary level, and four are highly 'marketised' comprehensive systems. All the more equal countries have comprehensive systems (Green \& Wiborg, forthcoming).

The following analysis focuses only on the Scandinavian countries [1]. Denmark, Norway and Sweden share in common an unusually extensive comprehensive school system. They have managed over time to integrate different types of schools into a single, unified public system in which nearly all children participate regardless of ability and social and economic background. In the process the private school sector has been reduced to insignificance, representing only a small proportion of schools and, in any case, being mostly subject to state subsidy and regulation. In Denmark, for instance, the state covers $80-85 \%$ of the expenditure of the private schools which in many cases are not so much elitist institutions but rather schools with a particular denominational, pedagogical or political orientation. Furthermore, the Scandinavian countries succeeded in creating common schooling for the whole length of the compulsory school age. Children stay together in the same un-streamed class from grade 1 to 9/10. The Scandinavian compulsory school, the enhedsskole, can therefore best be defined as an all-through, non-selective, public school with mixed ability classes covering the entire compulsory school age (Myhre, 1992; Richardson, 1999; Eckhoff, 2001; Markussen, 2003.

This is quite different from the understanding of comprehensive schools elsewhere. In England and Germany primary schools are largely comprehensive and non-selective but they are separated from the secondary schools. The latter are still 'officially' comprehensive in England but increasingly at least partially selective (Benn \& Chitty, 1996). In Germany secondary schools are mostly selective with only $9 \%$ of compulsory school age children attending a comprehensive Gesamtschule (Leschinsky \& Mayer, 1999). By comparison with England and Germany, Scandinavian children are obviously kept together in common schooling for a long time.

These shared characteristics of Scandinavian comprehensive education present an interesting case for comparative analysis. To date research on the comprehensive school movement in Scandinavia has been marked by being single country studies. The explanations given suffer from being nationally oriented with the result that particular causes reserved to one country may be over-emphasised. They are not 'tested' on the neighbouring countries in order to develop a more balanced theory. One example of this is the theory that held that Social Democracy was the main force behind the creation of comprehensive schooling in Sweden (Isling, 1984). Even though it is to a large extend correct, it fails to explain why the first steps towards making a comprehensive school were taken by liberals in all the Scandinavian countries long before Social Democracy gained a foothold.

The purpose of this article is to outline, as space allows, a framework of explanation for this common development the Scandinavian countries have undergone. Even though the countries differ from each other - the development towards the comprehensive system has indeed gone through three significant routes - they also show very similar traits. Generally it can be said that these countries show greater similarities between them than any of them 
separately could do to any other country outside this northern region. An analysis of the similarities and differences in the Scandinavian history of comprehensive schooling, therefore, can help to illuminate the process of cause and effect, since where the common factors are numerous the influence of distinctive causal factors should be all the easier to discover. The historical reasons behind the development of the unique forms of comprehensive schooling found in the Scandinavian countries are no doubt numerous, but the following analysis focuses four aspects that are taken to be the most central.

\section{State Intervention and the Establishment of a Public Education System}

The all-through system of education in Scandinavia has developed gradually over the last 150 years. However, the first important milestone in this process was the integration of the primary and secondary school into one system of education just before and after the beginning of the twentieth century. Hitherto, the secondary schools, whose roots went back to the Middle Ages, ran parallel to the elementary schools. Furthermore, the schools were characterised by different social intakes, as children of the professional classes were enrolled in the former and children of poor families, peasants and workers, in the latter. The single system of education was developed through the creation of a middle school that bridged between the elementary school and the secondary school. In this process the secondary school, which traditionally involved nine years of study, was reduced to three years in order to give room for the new four-year (in Sweden six-year) middle school, which followed on from the five-year (in Sweden three-year) elementary school. In Norway this was initially achieved through legislation 1869, which was then strengthened by further legislation in 1889. Danish and Swedish legislation followed after, respectively in 1903 and 1905/1909. These various Acts created in each country a linear school structure which replaced the old parallel systems. The three different school levels were now articulated with one another, so that all children, in principle, could now progress as far as their abilities allowed (Dokka, 1967; Sjöstrand, 1965; Skovgaard-Petersen, 1976). The system can be seen as the forerunner of the modern comprehensive school.

One precondition for this development was the fact that both the elementary and secondary schools were almost entirely public in all the Scandinavian countries. It can therefore be assumed that when the political will was present it was relative easy to bring the two school types together since they were both under state control. Had the secondary schools, conversely, been mainly private, it would more than likely have caused more conflicts than was the case. This is what the development in England suggests. Had the state in England sought to bring the elementary and secondary schools together one can imagine that there would have been insurmountable resistance by independent public schools and grammar schools (the latter were equivalent to the Scandinavian secondary schools). Even the creation of the 'upper tops' to elementary schools in the late nineteenth century, which acted as middle schools, thus encroaching on secondary school territory, caused consternation and they were largely abolished under the 1902 Balfour Act (Simon, 1974b). The independent secondary schools could successfully stay more or less outside the public system in England, because they had hardly been subject to state intervention during the nineteenth century. In Scandinavia the public elementary and secondary school was a result of state intervention.

Andy Green (1998) argues from his study of the development of national education systems in England, France, Germany and the USA that countries that were in the process of intensive state building were also among the earliest to establish public school systems. This argument could be extended to Scandinavia. Even though there are differences in the state building process in Denmark-Norway and Sweden, the two states, as they were then, 
both saw reforms to education during the period of reforming absolutism (Knudsen, 1995). The monarchs needed well-educated civil servants for the administrative bureaucracy and through reforming and financially supporting the secondary schools they created a close relationship between state and education. In England, the lack of state regulation of secondary education and the survival of a small civil service based on patronage until after the middle of the nineteenth century meant that there was not the close meritocratic linkage between the schools and the state that existed in Scandinavia (Mayer, 1981). By the end of the nineteenth century more than half of the secondary schools in Scandinavia were under state control and the rest, except for a very few, were not entirely private, since they were subject to state law and received state funding (Wennås, 1966; Skovgård-Petersen, 1976; Sirevåg, 1988).

The Scandinavian states, together with the church, initially promoted schooling for the lower classes in order to promote Christianity and to encourage patriotism and loyalty to the state. After an intensive period of reform in the late eighteenth century, a public system of schooling began to emerge in both the rural and urban areas. This was consolidated through laws for universal compulsory schooling, which were introduced in Denmark in 1814 and somewhat later in Norway (1824) and Sweden (1842). The public school systems thereafter became gradually more encompassing. Towards the end of the nineteenth century, even in the cities, which-especially in Denmark where they were larger-had greater class differentiation, a high percentage people started to send their children to the public elementary school (Sjöstrand, 1965; Dokka, 1967, p. 278; Skovgaard-Petersen, 1976). Had the long process of state intervention into education been absent, the integration of schools into a single system would probably have started later as in England, as well as being marked by stronger conflicts.

However, state formation theory cannot provide a full comparative explanation for the unique Scandinavian case since other countries were also in the process of intensive state building but never integrated their school system to the same degree as in Scandinavia. Prussia and France are examples of this. In Prussia the foundations of a national system of education were laid during absolutism and were gradually consolidated after the defeat to Napoleon in 1806, which had propelled a further state building process. However, during the last decades of the nineteenth century Prussia took a very different path from the Scandinavian countries. By contrast the nine-year Gymnasium, which ran parallel to other types of elementary and secondary schools, was maintained (Ringer, 1979). The middle school, introduced in 1872, was therefore not intended to create a connection between the elementary level and upper secondary level as in Scandinavia. Instead, the middle school was the official title of the remaining senior elementary schools and was essentially an institution designed to carry pupils a little beyond the level of the public primary schools.

\section{The Relative Egalitarianism of Scandinavian Societies}

The state theory can perhaps only explain the early timing of the integration process in Scandinavia. What remains to be explained is how the Scandinavian countries managed to abolish the lower part of the secondary school and to create, in its place, a middle school which would form the heart of a single education structure. The argument here is that it was the relative egalitarianism of the social structures in all the Scandinavian countries that made this possible. The vast majority of the population in each of the Scandinavian countries in the nineteenth century were peasant farmers with small and medium sized landholdings. The landed aristocracy in each country was very small as were the industrial bourgeoisie and the professional classes, unlike in the more industrialised countries such as England. In Norway, the landed aristocracy was almost absent. Instead the bourgeoisie formed the upper 
class. This peculiarity made the society unusually egalitarian even in comparison with Denmark and Sweden.

There were signs of the development of a more powerful aristocracy at certain historical points in Denmark and Sweden in the seventeenth century. However, the aristocracy had made their appearance on the historical stage comparatively late and their power and influence were substantially neutralized by other factors, above all by royal power. The nobility was not able to dominate government and the civil service as they were in England. Already from the eighteenth century the bourgeoisie were dominating them and in the following century peasants as well as teachers came onto the scene on a comparatively large scale (Jensen, 1954, p. 43; Semmingsen, 1954, p. 70; Carlsson, 1954, p. 90; Mayer, 1981).

At the other end of the social spectrum from the aristocracy, the peasants had their position considerably improved, especially through land sales. In Denmark, where feudal conditions of land ownership have been more marked, the liberation of the peasants from feudal ties to the nobility was initiated through land reform in the late eighteenth century, and in Sweden noble land sales started around the same time. In Norway, where there was little noble land owning, the sale of Crown land to peasants started even earlier. Around the middle of the nineteenth century more than half of the peasants owned their own land. The peasants - the medium sized farmers in Denmark and Sweden, and the smaller farmers in Norway-became an economically independent class. Being attached to the market, they were sensitive to the vagaries of the economy which where increasing, especially during the first half of the nineteenth century (Bonsdorff, 1954; Jensen, 1954; Semmingsen, 1954; Carlsson, 1954, 1973; Bjørn, 1988).

Another characteristic that made the countries relatively egalitarian was that industrial expansion did not begin on any scale until the latter half of the nineteenth century. Even when it did take off the process was slow and did not acquire the same momentum and force as in other West European countries, notably England and Germany. This was mainly due to lack of extensive natural resources. The result was a small-scale industrialism not marked by huge industries. It was only Sweden that managed to build a large-scale industry based on forestry and that it was not until after the First World War (Bonsdorrf, 1954).

What made these countries relatively egalitarian in their social structures was thus a complex of unique factors: the combination of a relatively small nobility with limited political influence and a large, independent Yeoman peasantry; the absence of large industrial magnates, and the lack of any sizeable industrial working class. Of course there existed a conflict of interest between the groups, but it was far from being on the same scale as seen in other countries such as England and Germany.

Consequently in none of the Scandinavian countries was there a bourgeoisie or landed upper class of sufficient size and political muscle to provide the recruitment base and political lobby power to provide a bulwark for the nine-year secondary schools against the reforming movement. Unlike in England, France and Germany, where the bourgeoisie and landed classes fought to maintain the integrity of the secondary schools that provided the guarantee of their social ascendancy, in the Scandinavian states there was no equal social basis maintaining the elite schools (Simon, 1974a; Mayer, 1981). Denmark and Sweden each had and still have only one private school comparable to the English public schools. Norway has none.

Another class related factor that served as a precondition for bringing the elementary school and the secondary schools together into one single system was that the elementary schools in the cities towards the end of the nineteenth century took in children from the bourgeois families. The school acts and increasing state support in this period had improved the schools to such a degree that they could compete with the private elementary schools, 
which served as pre-education for the secondary schools. The consequence was that the private elementary schools gradually vanished. This could make the public elementary school the base for the singular structure.

Furthermore, the secondary schools, which were dominated by the bourgeoisie, enrolled a significant proportion of children from the peasantry. Towards the end of the century the proportion of secondary students from peasant families was $16.5 \%$ in Denmark, $15 \%$ in Sweden and 18. \% in Norway (Skovgaard-Petersen, 1976; Dahn, 1936; Palmstrøm, 1936). Since the elementary school in Scandinavia, both in the country and the cities, increasingly served all classes, and since the secondary schools had an intake from the lower orders, especially from the peasantry, a very important precondition of bringing the two school types closer to each other was already in place.

\section{The Liberals and Education Reform}

State theory and class theory can thus both add to an explanation of the peculiarities of Scandinavian education, although they have their limitations. The nature of the state and the class structure cannot provide a complete explanation but they do serve as important preconditions for the political factors, which must take the major explanatory role. This leads to the third question, which is whether there existed a unique political situation in Scandinavia in contrast to countries such as England and Germany that can serve as another 'layer' in the explanation.

Common to all the countries was the fact that the peasants were the driving force behind establishing powerful liberal parties towards the end of the nineteenth century. These parties, in Denmark and Norway called venstre and in Sweden Lanntmannapartiet, could best be described as social-liberal parties. They put forward the idea of mixing social classes through a common school in order to create 'class-circulation'. The school system should furthermore be organised in such a way that students in spite of social background could advance through the whole system. The peasants whose social and economical position was strengthened through landownership, as mentioned before, became politically active at a rather early state. By organising associations from the 1840s and onwards, such as the important bondevennerne (the peasant friends), they sought to improve their own conditions. This paved the way to the establishment of political liberal parties and to substantial political influence (Lindblad, 1974). The Grundtvian Volk high schools, education centres for peasants, played an important role in enhancing their political involvement (Bugge, 1965). The liberal party obtained such a substantial political influence that they became a serious threat to the conservative establishment. By the end of the nineteenth century and the beginning of the twentieth century the conservative parties had basically lost their influence.

This is a sharp contrast to the political situation in England in late nineteenth century where organised skilled workers allied themselves to the Liberal party, but hardly dominated it. The Conservative party was in dominance towards the end of the nineteenth century and when the education system was reformed in 1902 it was done according to the advice education commissions, such as the Bryce Commission, that had advocated the maintenance of a class-based school system (Simon, 1974a). In Prussia land reform was also introduced, but in contrast to Denmark it was used to consolidate the Junker establishment with the result that peasants were not liberated to the same extent. The peasants did not form a party with social-liberal ideals but instead supported the conservative party, which dominated the political scene especially during the Bismarck era. Neither in England nor Germany did there exist a 'climate' for radical parties to gain a parliamentary foothold. The political struggle for comprehensive schooling was possible in Scandinavia in the late nineteenth century due to early peasant organisation and social-liberal values. 
Even though the peasant class formed their parties around the same time in Scandinavia, the introduction of a linear school structure happened at different times. Norway was ahead of its neighbouring countries, by having it introduced already in 1869 , more than twenty years earlier than Denmark and Sweden. The reason for this is first of all that Norway, in contrast to Denmark and Sweden, did not establish a bicameral political system in the traditional sense since there was no nobility to form an upper chamber. The consequence of this was that there could not arise a conservative resistance to reform from that side. Furthermore, peasants and teachers were already dominating the government at the beginning of the nineteenth century. When the liberal member, Johan Sveidrup, came onto the political scene, he received wide support from the peasants when he introduced the reform. In Denmark and Sweden a bicameral system was introduced, and in Sweden the upper chamber turned down several reform plans presented by the liberals from the first chamber.

Furthermore, in these two countries the question of comprehensive schooling also got caught in the parliamentary conflict that went on between the liberals and the conservatives in the last three decades of the century. That delayed the introduction of the system. But when the liberals won that fight they took the opportunity to introduce straight away the middle school in 1903 in Denmark (by education minister J.C. Christensen) and in 1905 in Sweden (by education minister F. Berg).

\section{The Rise of Social Democracy and the Abolishment of the Middle School}

After the First World War the political efforts to go further on the lines of comprehensiveness were particularly evident. The second milestone was the abolishment of the middle school in order to create an all-through system of education in all the compulsory school years. That happened in Norway in two steps, in 1920 and 1935, in Denmark in 1958 and in Sweden in 1962. That, in turn, paved the way to create a nine/ten year common school in all the Scandinavian countries (Bregnsbo, 1971; Isling, 1984; Myhre, 1992; Richardson, 1999). During this era the liberal party was weakened, mainly because less people were occupied in agriculture. Another party, the Social Democrats, grew in influence and soon started to influence education policy. The social democratic parties were established at the end of the nineteenth century in all of the Scandinavian countries and were quick to take up educational questions, mainly concerning primary education. They took over to a large extent the education program of the liberal parties and added to them their own socialistic beliefs. They argued for common schools on social solidarity grounds like the liberals but added to that stronger arguments relating to equality and mobility. Their demand for comprehensive schooling meant basically that it should extend to all the compulsory school years with streaming as late as possible and no setting of any kind. This argument, however, belonged more to the time after the Second World War.

As Esping-Andersen (1985) has noted, it is peculiar that these pre-industrial Scandinavian 'peasant countries' would produce such similar and powerful social democratic movements. It must be explained by a combination of late industrialization in a somewhat democratic political setting and, of most importance, an independent peasantry capable of allying with workers in the fight for democracy. Social democracy could not have obtained a powerful position in between the Wars had it not been for their ability to ally themselves with the peasantry.

It was the peculiarly organized and democratic character of the Scandinavian peasantry, he argues, that enabled social democracy to gain a foothold; and it was the absence thereof that stifled socialist parties elsewhere, most notably in Germany (Esping-Andersen, 1985). Furthermore, the party's ability to appeal to voters beyond the urban working class helped 
them to escape from political isolation. He agues that one of the most important preconditions for social democracy in the post war period was the movement's ability to exchange alliance partners, drop the petit-bourgeoisie, and seek a coalition with the new middle strata. The state played an important role in this since white-collar employment got concentrated in the public sector and they had a larger affinity to labour than the private sector employees. Bourgeois resistance was generally modest and, even under limited suffrage, the socialists had managed to gain representation and affect policy at both the local and the national level.

This period gave rise to a political pattern of lasting influence. In Denmark the conservatives and the liberals were the two dominant bourgeois parties, the social democrats became the largest party on the left, and the radicals, who were offspring of the liberals, occupied a left of centre position as allies to the social democracy. The political arrangement was similar in Norway and Sweden with the difference that Social Democracy was more powerful in Sweden, where they had a larger working class, than in Denmark and Norway, where liberals played a stronger role on account of the historical longevity of the farmingbased economies in these countries. In all education legislation these parties in coalition with each other played the major role. It is hard to find any piece of legislation that is not a product of these three consensus-seeking parties. For all the countries the conservative parties were relative weak, and this is why they were not able to protect the secondary school from being reduced from nine to three years as their sister party were able to in Germany.

Though not free of struggles the parties, in close cooperation, succeeded in abolishing the middle school in order to create an all-through school in all the Scandinavian countries. Norway was quicker in this than Denmark and Sweden. In 1920 the middle school was reduced from four to two years in order to create an extended elementary school, now seven years long. In 1936 the middle school was completely abolished and in 1969 a nine-year non-selective integrated school was created. In 1994 it was extended by another year, by lowering the school start from age seven to six (Myhre, 1992; Eckhoff, 2001). In Denmark the middle school was abolished in 1958 and a seven-year common school was introduced (Bregnsbo, 1971) and in 1975 a nine-year comprehensive school was created. In 1993 the last traces of setting were abolished, so now there existed a completely non-selective, unstreamed, comprehensive school (Markussen, 2003). In Sweden a nine-year school was not fully introduced until 1962, but since the 1950s comprehensive schools had been quite widespread as a result of the 1950 Act that instructed schools to experiment with the nineyear long comprehensive school model. Furthermore, especially in the 1970s and afterwards, the development went in the direction of abolishing setting in order to created mixed ability classes (Marklund, 1980).

\section{Conclusion}

Four different arguments accounting for this unique development have been outlined. It was shown that early state involvement in education resulted in a public school system at both elementary and secondary level. This was believed to have served as an important precondition of bringing the two systems together into a linear structure. However, since early state intervention was not unique to Scandinavia, this factor cannot provide a full comparative explanation. Countries such as Germany and France also created public school systems but never integrated their systems to the same degree as did the Scandinavians. The second argument was that the relatively egalitarian class structure in contrast to Germany and England served as an important precondition for this development. First of all there did not exist an elite to maintain an extensive private school sector. Second, both the elementary 
school and secondary school broadened their social intake mix and this served as an important enabler for the politicians who wanted to abolish the lower part of the secondary school to create a linear structure in the name of greater social class mixing.

The third argument concerned the nature of the political parties and the political balance of forces. The political scene at the end of the nineteenth century differed substantially between the Scandinavian and other countries considered here and this seems to have had important implications for education. It can be said that the Scandinavian countries did indeed share a unique political situation in comparison with Germany and England. The peasantry who organised themselves in the beginning of the nineteenth century had a long and lasting influence in the liberal party that was based on social-liberal ideas. The radical political climate they created paved the way for liberal politicians to introduce the linear school structure. It was a less difficult process in Norway and Denmark than in Sweden mainly due to the fact that in Norway, especially, there was a more sparse population, a less elite-dominated society and a weaker academic tradition. In Denmark and Sweden, elite society was more robust as can be seen from the bicameral political organisation of parliament as well as in the stronger academic tradition in education. The elites were more successful in delaying the introduction of comprehensive schooling, but not for long. By contrast, political dominance by the bourgeoisie and landowners in both Germany and England did not leave much possibility for this kind of comprehensive reform. Instead the Gymnasium and the Grammar schools were maintained as full lower and upper secondary systems in parallel to the popular elementary education systems.

The fourth argument relating to the influence of social democracy can provide the final explanation of why all the Scandinavian countries created more radical comprehensive systems, especially after the Second World War. Compared with other countries such as Germany and England, social democracy was far more powerful: Social Democrats were in power for longer and had a more substantial influence on education legislation. Their ability to work in close connection to the liberal parties ensured them this. Their power made it possible for them not to take their starting point from elitist institutions, which would then frame the remaining part of the educational system. The process of creating a comprehensive system started, instead, from below and proceeded by extending the elementary schools into the secondary phase. The result of this was a system of allthrough, mixed-ability, comprehensive education which is unique, at least in Europe, to the Scandinavian states.

Correspondence: Susanne Wiborg, The Danish University of Education, Emdrupvej 101, 2400 København NV, Denmark. Email: sws@dpu.dk

\section{Notes}

[1] Iceland and Finland are normally included in the Nordic countries and share similar education structure as the Scandinavian countries. However, only the three Scandinavian countries will in this article be dealt with.

[2] Although similar forms can be found in Russia.

\section{References}

Benn, C. \& Chitty, C. (1996) Thirty Years On. Is Comprehensive Education Alive and Well or Struggling to Survive?, London, David Fulton Publishers.

BJøRn, C. (1988) Det danske landbrugs historie III: 1810-1914, Odense, Landbohistorisk Selskab. 


\section{S. Wiborg}

BONSDORFF, G. von (1953) Studier rörande den moderna liberalismen i de nordiska länderna. Lund, CWK Gleerup.

Bregnsbo, H. (1971) Kampen om skolelovene af 1958: En studie i interesseorganisationers politiske aktiviteter, Odense, Odense University Press.

BuGGE, K.E. (1965) Skolen for livet: studier over N.F.S. Grundtvigs pædagogiske tanker, København, Gads Forlag.

CARLsson, S. (1954) Ståndsupplösning och demokratisering i Sverige efter 1780, in Ståndssamhällets upplösning i Norden, Åbo, Turku.

Carlsson, S. (1979) Ståndssamhälle och ståndspersoner 1700-1865, Lund, CWK Gleerup Bokförlag.

DAHN, P. (1936) Studier rörande den studerande ungdomens geografiska och sociala härkomst, Lund, Håkon Ohlssons boktryckeri.

Dокка, H-J. (1967) Fra allmueskole til folkeskole, Bergen, Universitetsforlaget.

Eckнoff, N. (2001) Einskapsskolens historie i Noreg, Oslo, Det Norske Samlaget.

Esping-Andersen, G. (1985) Politics Against Market, Princeton, NJ, Princeton University Press.

Esping-Andersen, G. (forthcoming) Unequal opportunities and social inheritance. In M. Corak (ed.) The Dynamics of Intergenerational Income Mobility, Cambridge, Cambridge University Press.

Green, A. (1990) Education and State Formation. The Rise of Education Systems in England, France and the USA, London, Macmillan.

GreEN, A. \& Wiborg, S. Comparative schooling and educational inequality: an international perspective. In C. Chitтr (ed.) For Caroline Benn: essays in education and democracy. Continuum.

IsLING, Å. (1984) Kampen för och mot en demokratisk skola 1, Stockholm, Sober Förlags AB.

JeNSEn, S. (1954) Stands- og klasseforhold i Danmark i tiden mellem slutningen af 1700-tallet og i dag, i Ståndssamhällets upplösning i Norden, Åbo, Turku.

KNudsen, T. (1995) Dansk statsbygning, København, Jurist- og økonomforbundets Forlag.

Leschinsky, A. \& MAYER, K. (1999) (eds) The Comprehensive School Experiment Revisited: evidence from Western Europe, Berlin, Peter Lang.

Lindblad, I. (1974) Politik i Norden. Enjämförande översikt, Stockholm, Bokförlaget Aldus/ Bonniers.

Markiund, S. (1980) Från reform till reform. Skolesverige 1950-1975. Del 1. 1950 års reformbeslut, Stockholm, Liber UtbildningsFörlaget.

Markussen, I. (2003) Dannelsessyn og drivkraefter bag enhedsskolens fremvaekst. In R. SlaGstad (ed.) Dannelsens forvandlinger, Oslo, Pax Forlag.

MaYer, A. (1981) Persistence of the Old Regime: Europe to the Great War, London, Croom Helm.

Myнre, R. (1992) Den norske skoles udvikling. Ide og virkelighed, Oslo, Gyldendal Norsk Forlag.

Mülier, D.K., Ringer, F. \& Simon, B. (1987) The Rise of the Modern Educational System: structural change and social reproduction 1870-1920, Cambridge, Cambridge University Press.

OECD (2000) Literacy in the Informnation Age: Final report of the International Adult Literacy Survey, Paris, OECD.

Palmström, H. (1935) Om en befolkningsgruppes utvikling gjennem de siste 100 år. Statistiske studier vedrørende norske akademikere, Oslo, Særtryk af statsøkonomisk tidsskrift.

Richardson, G. (1999) Svensk utbildningshistoria. Skola och samhälle förr och nu, Lund, Studentlitteratur.

RingeR, F. (1979) Education and Society in Modern Europe, Bloomington, Indiana University Press.

Semmingsen, I. (1954) 'Standssamfunnets opplösning i Norge', in Ståndssamhällets upplösning i Norden, Åbo, Turku. 
Shavit, Y. \& Blossfeld, H-P. (1983) Persistent Inequality: changing educational educational attainment in thirteen countries, Boulder, CO, Westview Press.

SIREVÅG, T. (1998) Utsyn over norsk høgre skole. Frå lærde skolar til lov om vidaregåande opplaring, Oslo, Univeristetsforlaget.

Simon, B. (1974a) The Two Nations and the Education Structure: 1780-1870, London, Lawrence \& Wishart.

Simon, B. (1974b) Education \& the Labour Movement 1870-1920, London, Lawrence \& Wishart. Sjöstrand, W. (1965) Pedagogikens Historia 3:2, Lund, CWK Gleerups Förlag.

SkovgaArd-Petersen, V. (1976) Dannelse og demokrati, København, Gyldendals pædagogiske bibliotek.

Wennås, O. (1966) Striden om latinväldet. Idéer och intressen i svensk skolpolitik under 1800-talet, Stockholm, Almqvist \& Wiksell.

Winther-Jensen, T. (2002) The tradition and transition in Danish education. In R. Griffin (ed.) Education in Transition. International Perspectives on the Politics and Process of Change, Oxford, Symposium Books. 
